\title{
Metformin's Modulatory Effects on miRNAs Function in Cancer Stem Cells-A Systematic Review
}

\author{
Bartosz Malinowski *, Nikola Musiała and Michał Wiciński \\ Department of Pharmacology and Therapeutics, Faculty of Medicine, Collegium Medicum in Bydgoszcz, \\ Nicolaus Copernicus University, M. Curie 9, 85-090 Bydgoszcz, Poland; nicole.musiala@gmail.com (N.M.); \\ wicinski4@wp.pl (M.W.) \\ * Correspondence: bartosz.malin@gmail.com
}

Received: 29 April 2020; Accepted: 2 June 2020; Published: 4 June 2020

\begin{abstract}
Cancer stem cells (CSCs) have been reported in various hematopoietic and solid tumors, therefore, are considered to promote cancer progression, metastasis, recurrence and drug resistance. However, regulation of CSCs at the molecular level is not fully understood. microRNAs (miRNAs) have been identified as key regulators of CSCs by modulating their major functions: self-renewal capacity, invasion, migration and proliferation. Various studies suggest that metformin, an anti-diabetic drug, has an anti-tumor activity but its precise mechanism of action has not been understood. The present article was written in accordance to the PRISMA (Preferred Reporting Items for Systematic Reviews and Meta-Analyses) guidelines. We systematically reviewed evidence for metformin's ability to eradicate CSCs through modulating the expression of miRNAs in various solid tumors. PubMed and MEDLINE were searched from January 1990 to January 2020 for in vitro studies. Two authors independently selected and reviewed articles according to predefined eligibility criteria and assessed risk of bias of included studies. Four papers met the inclusion criteria and presented low risk bias. All of the included studies reported a suppression of CSCs' major function after metformin dosage. Moreover, it was showed that metformin anti-tumor mechanism of action is based on regulation of miRNAs expression. Metformin inhibited cell survival, clonogenicity, wound-healing capacity, sphere formation and promotes chemosensitivity of tumor cells. Due to the small number of publications, aforementioned evidences are limited but may be consider as background for clinical studies.
\end{abstract}

Keywords: cancer stem cells; metformin; miRNA

\section{Introduction}

Cancer stem cells (CSCs) are a subpopulation of cancer cells that have the ability to self-renew, differentiate into different cell types and to arrest in the G0 phase. Therefore, CSCs may be the main reason for the failure of cancer treatment, by causing metastasis, recurrence and resistance to therapy [1,2]. In the 1990s, CSCs were identified in acute myeloid leukemia (AML) [3,4]. Bonnet and Dick [4] described CD $34^{+} \mathrm{CD} 38^{-}$leukemic cells that could initiate AML in NOD/SCID (non-obese diabetic/severe combined immunodeficiency) mice. Further research has provided evidence of the presence of CSCs in many solid tumors, for example, breast [5], ovarian [6,7] and pancreatic [8,9].

Since the first studies on CSCs' existence, the expression of cell surface markers has been used to isolate and identify CSCs, differentiating them from many types of cancers [4-6]. There are plenty of common or unique surface markers that have been associated with solid or hematopoietic tumors, for example, $\mathrm{CD} 34^{+} \mathrm{CD} 38^{-}$for AML [4]; CD44 ${ }^{+} \mathrm{CD} 24^{-} /$lowLin- [5] and ALDH+ [10] for breast cancer; $\mathrm{CD}_{4} 4^{+}[11], \mathrm{CD} 44^{+} \alpha 2 \beta 1^{+}$[12] and ALDH+ [13] for prostate cancer; $\mathrm{CD} 44^{+} \mathrm{CD} 117^{+}[7], \mathrm{CD} 24^{+}[14]$, 
ALDH+ [15] and CD133 ${ }^{+}$[16] for ovarian cancer. Heterogeneity of CSCs are complex and it is still unclear if phenotypically heterogeneous CSCs populations are also functionally different [17].

It is of great importance to understand the characteristics of CSCs. Like normal stem cells (NSCs), a major property of CSCs is their ability to self-renew [18]. In NSCs there are many signaling pathways that are strictly controlled, for example, Wnt/ $\beta$-catenin, Notch, Hedgehog $(\mathrm{Hh})$ and B-cell-specific Moloney murine leukemia virus integration site 1 (BMI1). However, due to epigenesis those self-renewal pathways (SRPs) are deregulated in CSCs [19]. It is still poorly understood how CSCs are regulated at the molecular level $[18,19]$.

Recent studies of microRNAs (miRNAs) have introduced their new major role in regulatory mechanisms in CSCs [20]. miRNAs are small molecules (21-25 nucleotides long), that belong to a class of non-coding RNAs. Through binding to the $3^{\prime}$-untranslated regions ( $3^{\prime}$-UTR) of target mRNAs, miRNAs regulate gene expression [21]. Various studies indicate that miRNAs are involved in a wide range of cell functions, such as development, proliferation, differentiation, apoptosis and self-renewal $[22,23]$. Those evidences link miRNAs to the regulatory mechanisms at the molecular level of NSCs and CSCs. Moreover, through the regulation of the key biological properties of CSCs, it has become evident that miRNAs are involved in tumorigenesis [23].

Traditional cancer treatment may not affect CSCs due to their mechanism of drug resistance. CSCs are mostly arrested in the G0 phase; they express ATP-binding cassette (ABC) transporters (ABCB1, $A B C C 1, A B C G 2)$ and prevent cancer cells from apoptosis. The ABC transporters use energy from ATP hydrolysis to translocate various substances across the cell membrane. Overexpression of $A B C$ proteins is the main protective mechanism for CSCs from various agents. Additionally, aldehyde dehydrogenase (ALDH), a cytosolic enzyme that oxidizes aldehydes, enhances resistance to chemotherapy and radiotherapy through protecting CSCs from oxidative stress. The drug-resistance characteristics of CSCs play an essential role in cancer progression and relapse [24,25]. It is crucial to develop new therapeutic strategies that target CSCs. Recent studies have been focused on a well-known drug-metformin — that may play a major role in regulation of miRNAs functions [26]. Metformin is an anti-hyperglycemic agent that is widely used for treating patients with type-II DM (diabetes mellitus) and also with polycystic ovarian syndrome (PCOS). Despite the widespread use of metformin, the molecular mechanisms of action of the drug are still largely debated [27,28]. Metformin acts through inhibition of the complex I of the mitochondrial respiratory chain which increases the cellular AMP:ATP ratio [29]. AMP-activated protein kinase (AMPK) is a key enzyme of energy homeostasis that is activated through change in the AMP:ATP ratio [30,31]. Metformin-mediated AMPK activation results in down-regulation of hepatic gluconeogenesis and up-regulation of glucose intake in peripheral tissue [31]. Interestingly, numerous studies bring a new possibility in metformin usage. It is considered, that metformin may function as an anti-tumor agent through regulation of miRNAs and CSCs $[26,28]$.

Therefore, in this systematic review recent evidence of metformin influence on miRNAs and CSCs regulation in solid tumors will be discussed and summarized.

\section{Methods}

\subsection{Data Sources and Searches}

Two independent authors searched PubMed and MEDLINE for all published results between January 1990 and January 2020 on metformin influence on cancer stem cells through regulation of miRNAs. The following search terms were used: "neoplastic stem cells"(MeSH Terms) OR "neoplastic"(All Fields) AND "stem"(All Fields) AND "cells"(All Fields) OR "neoplastic stem cells"(All Fields) OR "cancer"(All Fields) AND "stem"(All Fields) AND "cells"(All Fields) OR "cancer stem cells"(All Fields)) AND "metformin"(MeSH Terms) OR "metformin"(All Fields) AND "micrornas"(MeSH Terms) OR “micrornas"(All Fields) OR “mirna”(All Fields) OR "miR"(All Fields). Investigators also searched the bibliographies of relevant articles. 


\subsection{Eligibility Criteria}

Present systematic review was conducted in accordance with PRISMA (Preferred Reporting Items for Systematic Reviews and Meta-analyses) statement.

The PICO criteria:

Population: cells from human solid tumors that exhibit CSCs characteristics

Intervention: metformin

Comparison: cells without metformin treatment

Outcome: changes in miRNAs expression; inhibition of cell proliferation, migration, invasion and self-renewal capacity; inhibition of sphere formation

All published studies were only included if they were written in English and performed in in vitro experiments. However, included papers could additionally perform in vivo studies on mice. We also accepted articles that compared mechanism of action of metformin with other interventions that regulate miRNAs expression. Clinical trials were excluded from the present paper.

\subsection{Study Selection}

Two investigators (N.M., B.M.) independently reviewed each study's title and abstract according to the prespecified eligibility criteria. Abstracts of interest were included for full-text analysis. Afterwards, two authors analyzed all full-text articles and rejected those that did not meet the aforementioned PICOs criteria. Any inconsistencies between the two reviewers were resolved by discussion with a supervisor (M.W.).

\subsection{Data Collection Process and Data Items}

All included articles were analyzed independently by the two authors (N.M., B.M.). The abstracted information included author names, year of publication, study design, cell line, animal model, intervention, dose of intervention, type of miRNA and main outcomes. The supervisor (M.W.) checked the abstracted information and resolved any disagreements.

\subsection{Data Synthesis Analysis}

Two investigators (N.M., B.M.) independently assessed the risk of bias in selected studies using predefined criteria. However, there is no standard risk-of-bias tool for in vitro studies; so methodological studies by criteria developed in the systematic reviews of in vitro studies (Tables 1 and 2) were assessed [32]. Two authors (N.M., B.M.) independently categorized included studies as "low", "moderate" or "high" quality. Any disagreements were resolved through discussion.

Table 1. Reporting quality scheme.

\begin{tabular}{lclll}
\hline & & & The Presence of the Information about \\
Study Design & \\
\hline & $\begin{array}{c}\text { Is the cell origin } \\
\text { and cell type used } \\
\text { reported? }\end{array}$ & Reported & $\begin{array}{c}\text { Not clearly } \\
\text { reported }\end{array}$ & Not reported \\
\cline { 2 - 5 } Reporting quality & $\begin{array}{c}\text { Is the dose of } \\
\text { exposure reported? }\end{array}$ & Reported & $\begin{array}{c}\text { Not clearly } \\
\text { reported }\end{array}$ & Not reported \\
\cline { 2 - 5 } & $\begin{array}{c}\text { Is the time of } \\
\text { exposure reported? }\end{array}$ & Reported & $\begin{array}{c}\text { Not clearly } \\
\text { reported }\end{array}$ & Not reported \\
\hline
\end{tabular}


Table 2. Reporting the risk of bias scheme.

\begin{tabular}{|c|c|c|c|c|}
\hline & & $\begin{array}{r}\text { The } \\
\text { Informatic }\end{array}$ & $\begin{array}{l}\text { the } \\
\text { k of Bias }\end{array}$ & Risk Unknown \\
\hline \multirow{3}{*}{ Performance bias } & $\begin{array}{l}\text { Was the exposure } \\
\text { randomized? }\end{array}$ & Yes & No & Not reported \\
\hline & $\begin{array}{l}\text { Was the exposure } \\
\text { blinded? }\end{array}$ & Yes & No & Not reported \\
\hline & $\begin{array}{l}\text { Have more than one } \\
\text { cell lines been used? }\end{array}$ & Yes & No & - \\
\hline \multirow{2}{*}{ Selection bias } & $\begin{array}{l}\text { Is the cell vitality } \\
\text { scored/measured? }\end{array}$ & Yes & No & Not reported \\
\hline & $\begin{array}{l}\text { Were all measured } \\
\text { outcomes reported? }\end{array}$ & Yes & No & Not reported \\
\hline Detection bias & $\begin{array}{l}\text { Were the experimental } \\
\text { conditions the same for } \\
\text { control and exposure } \\
\text { treatment? }\end{array}$ & Yes & No & Not reported \\
\hline Other bias & $\begin{array}{l}\text { Was there no industry } \\
\text { sponsoring involved? }\end{array}$ & Yes & No & Not reported \\
\hline
\end{tabular}

\section{Results}

\subsection{Study Selection}

The electronic search from aforementioned databases revealed 25 articles in English. Of these, 19 were excluded after reading the title and abstract. The remaining 6 articles were included for full-text screening. Afterwards, 4 publications were included as they meet the inclusion criteria for this systematic review (Figure 1).
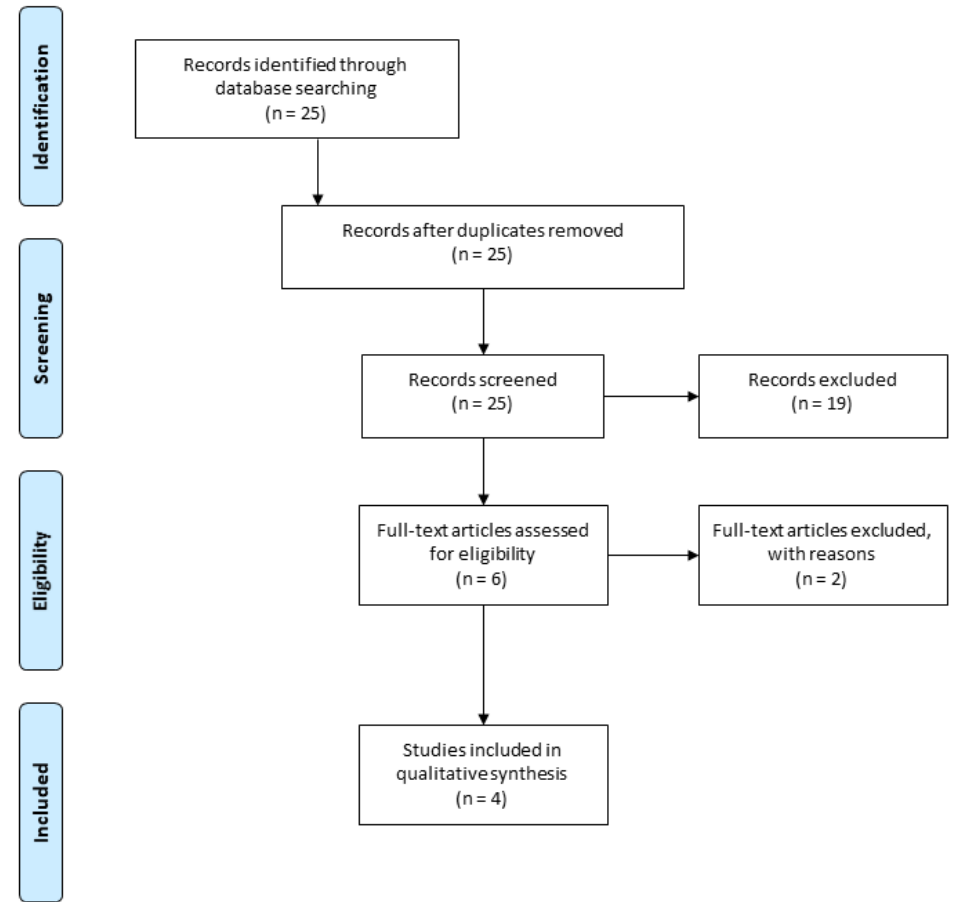

Figure 1. The Preferred Reporting Items for Systematic Reviews and Meta-Analyses (PRISMA) flow chart. 


\subsection{Study Characteristics}

Characteristics of included studies are presented in Table 3. All articles were published between 2011 and 2019 and were written in English [33-36]. Studies have been carried out on two types of cancers: breast cancer $[33,34,36]$ and pancreatic cancer [35]. The studies were conducted in the USA $(n=1)$ [35], Spain $(n=1)$ [36], Japan $(n=1)$ [34] and in China $(n=1)$ [33]. All four studies were performed in vitro [33-36], three of them also involved in vivo studies on animals (female BALB/C nude mice [33]; female NON/SCID mice [34]; female CB17/SCID mice [35]). Two studies analyzed cancer tissues from patients who underwent primary breast surgery for stage I-III [33] or II-III [34] invasive breast carcinoma. All studies used metformin as an intervention [33-36], one of them also used transforming growth factor $\beta 1$ (TGF $\beta 1$ ) with or without metformin [36]. The included papers examined the effects of metformin on expression of various miRNAs in cancer cells: microRNA-708 (miR-708) in breast cancer [33]; microRNA-27b (miR-27b) in breast cancer [34]; let-7a, microRNA-181a (miR-181a), and microRNA-96 (miR-96) in breast cancer [36]; let-7 family, microRNA-200 family (miR-200), microRNA-101 (miR-101) and microRNA-26a in pancreatic cancer [35]. Additionally, three articles showed the effect of metformin on the mRNA expression of CSCs marker genes [33-35]. Two papers examined the inhibition of spheres formation in cells treated with metformin $[35,36]$. 
Table 3. Studies' characteristics.

\begin{tabular}{|c|c|c|c|c|c|c|c|}
\hline Author, Year & Study Design & Type of Cancer & Cell Lines & Animal & Intervention & miRNA & Main Outcomes \\
\hline Tan et al., 2019 [33] & $\begin{array}{l}\text { In vitro and } \\
\text { in vivo }\end{array}$ & Breast cancer & $\begin{array}{l}\text { MDA-MB-231, } \\
\text { MCF-7 }\end{array}$ & $\begin{array}{c}\text { female } \mathrm{BALB} / \mathrm{c} \\
\text { nude mice }\end{array}$ & Metformin & miR-708 & $\begin{array}{c}\text { Increased } \\
\text { chemosensitivity and } \\
\text { attenuated CSCs. }\end{array}$ \\
\hline $\begin{array}{l}\text { Takahashi et al., } \\
2015 \text { [34] }\end{array}$ & $\begin{array}{l}\text { In vitro and } \\
\text { in vivo }\end{array}$ & Breast cancer & $\begin{array}{l}\text { MCF-7, ZR75-1, } \\
\text { MDA-MB-231 }\end{array}$ & $\begin{array}{c}\text { female NON/SCID } \\
\text { mice }\end{array}$ & Metformin & $\operatorname{miR}-27 \mathrm{~b}$ & $\begin{array}{c}\text { Increased } \\
\text { chemosensitivity and } \\
\text { inhibited tumor seeding } \\
\text { ability in CSCs. }\end{array}$ \\
\hline Bao et al., 2011 [35] & $\begin{array}{l}\text { In vitro and } \\
\text { in vivo }\end{array}$ & Pancreatic cancer & $\begin{array}{c}\text { AsPC-1, } \\
\text { AsPC-1-GTR, } \\
\text { MiaPaCa-2, } \\
\text { MiaPaCa-2-GTR }\end{array}$ & $\begin{array}{l}\text { female CB17/SCID } \\
\text { mice }\end{array}$ & Metformin & $\begin{array}{l}\text { miR-26a; let-7; } \\
\text { miR-200; } \\
\text { miR-101; }\end{array}$ & $\begin{array}{c}\text { Suppression } \\
\text { self-renewal capacity, } \\
\text { proliferation, migration } \\
\text { and invasion in CSCs. }\end{array}$ \\
\hline $\begin{array}{l}\text { Oliveras-Ferraros et al., } \\
2011 \text { [36] }\end{array}$ & In vitro & Breast cancer & MCF-7 & none & $\begin{array}{l}\text { Metformin; } \\
\text { Metformin + } \\
\text { TGF } \beta 1\end{array}$ & $\begin{array}{l}\text { let-7a; miR-181a; } \\
\text { miR-96 }\end{array}$ & $\begin{array}{c}\text { Suppression TGF } \beta 1 \\
\text { functions and } \\
\text { dedifferentiation } \\
\text { processes. }\end{array}$ \\
\hline
\end{tabular}

Cancer stem cells (CSCs); non-obese diabetic/severe combined immunodeficiency (NON/SCID); transforming growth factor $\beta 1$ (TGF $\beta 1$ ). 


\subsection{Quality and Risk of Bias}

All included papers were analyzed for risk of bias (Tables 4 and 5). Three of them were considered "high" quality of evidence [33-35]. One study used only one cell line (MCF-7 cells) and was considered "moderate" quality [36]. Therefore, four included articles were considered as significant in reporting a potential effect of metformin on regulation of miRNAs expression and CSCs functions [33-36].

Table 4. Assessment of the quality of the included studies.

\begin{tabular}{cccccc}
\hline & Tan et al. [33] & $\begin{array}{c}\text { Takahashi et al. } \\
\text { [34] }\end{array}$ & Bao et al. [35] & $\begin{array}{c}\text { Oliveras-Ferraros } \\
\text { et al. [36] }\end{array}$ \\
\hline & $\begin{array}{c}\text { Is the cell origin } \\
\text { and cell type } \\
\text { used reported? }\end{array}$ & Reported & Reported & Reported & Reported \\
\cline { 2 - 6 } $\begin{array}{c}\text { Reporting } \\
\text { quality }\end{array}$ & $\begin{array}{c}\text { Is the dose of } \\
\text { exposure } \\
\text { reported? }\end{array}$ & Reported & Reported & Reported & Reported \\
\cline { 2 - 6 } & $\begin{array}{c}\text { Is the time of } \\
\text { exposure } \\
\text { reported? }\end{array}$ & Reported & Reported & Reported & Reported \\
\hline
\end{tabular}

Table 5. Assessment of the risk of bias of the included studies.

\begin{tabular}{|c|c|c|c|c|c|}
\hline & $\begin{array}{l}\text { Was the Exposure } \\
\text { Randomized? }\end{array}$ & Not Reported & Not Reported & Not Reported & Not Reported \\
\hline \multirow{2}{*}{ Performance bias } & $\begin{array}{l}\text { Was the exposure } \\
\text { blinded? }\end{array}$ & Not reported & Not reported & Not reported & Not reported \\
\hline & $\begin{array}{l}\text { Has more than one } \\
\text { cell line been used? }\end{array}$ & Yes & Yes & Yes & No \\
\hline \multirow[b]{2}{*}{ Selection bias } & $\begin{array}{l}\text { Is the cell vitality } \\
\text { scored/measured? }\end{array}$ & Yes & Yes & Yes & Yes \\
\hline & $\begin{array}{l}\text { Were all measured } \\
\text { outcomes } \\
\text { reported? }\end{array}$ & Yes & Yes & Yes & Yes \\
\hline Detection bias & $\begin{array}{l}\text { Were the } \\
\text { experimental } \\
\text { conditions the } \\
\text { same for control } \\
\text { and exposure } \\
\text { treatment? }\end{array}$ & Yes & Yes & Yes & Yes \\
\hline Other bias & $\begin{array}{l}\text { Was there no } \\
\text { industry } \\
\text { sponsoring } \\
\text { involved? }\end{array}$ & Not reported & Yes & Yes & Not reported \\
\hline
\end{tabular}

\subsection{Results of Studies}

\subsection{1. miRNAs Expression in Tumors}

Tan et al. [33] analyzed miR-708 expression in the following cells derived from MDA-MB-231 and MCF-7 cells: spheres and adherent cells; non CD44 ${ }^{+} / \mathrm{CD} 24^{-}$and $\mathrm{CD} 44^{+} / \mathrm{CD} 24^{-}$population; cells treated with miR-708 knockdown or not; chemo resistant cell lines MCF-7ADR. miR-708 expression decreased significantly in mammospheres, $\mathrm{CD} 44^{+} / \mathrm{CD} 24^{-}$population and in MCF-ADR cells. Moreover, cells treated with miR-708 knockdown showed enhancement of the mammospheres formation ability. Direct target of miR-708 has been identified as CD47. Additionally, overexpression of miR-708 or downregulation of CD47 induced sensitivity of MDA-MB-231 cells to docetaxel and increased the phagocytosis in all four cell lines [33]. Takahasi et al. [34] showed that downregulation of miR-27b induces drug resistance through formation of the SP fraction (side-population cells) of MCF-7 and ZR75-1 cells. Reduction of SP fraction occurs as a result of miR-27b suppression of the ectonucleotide 
pyrophosphatase/phosphodiesterase 1 (ENPP1) gene that leads to the inhibition of the expression and cell surface localization of ATP-binding cassette super-family G member 2 (ABCG2) transporter. Moreover, they confirmed that downregulation of miR-27b is associated with the generation of the high tumor seeding ability and chemoresistance population of luminal-type breast cancer cells, $\mathrm{CD} 44^{+} / \mathrm{CD} 24^{-}$[34]. Bao et al. [35] examined the role of miR-26a, let-7b and miR-200b in pancreatic cancer cells. In MiaPaCa-2 cells, transfection of miR-26a precursor increased relative expression of miR-26a which caused a decrease in levels of enhancement of zeste homolog 2 (EZH2) and epithelial cell adhesion molecule (EpCAM) proteins and mRNA levels of EZH2, EpCAM, Oct4 and Notch-1. Additionally, investigators demonstrated that re-expression of let- $7 \mathrm{~b}$ and miR-26a decreased the formation of pancreatospheres in MiaPaCa-2 cells [35]. The results discussed above confirm that some miRNAs inhibit major properties of CSCs, such as drug resistance and self-renewal ability (Table 6) [33-35].

Table 6. Analysis of miRNAs expression in tumor cells.

\begin{tabular}{|c|c|c|c|c|}
\hline Author & $\begin{array}{l}\text { Type of Tumor } \\
\text { Cells }\end{array}$ & Type of miRNA & Target Expression & $\begin{array}{l}\text { Effect of miRNA } \\
\text { Regulation }\end{array}$ \\
\hline Tan et al. [33] & breast cancer cells & miR-708 & $\begin{array}{c}\downarrow \mathrm{CD} 47 \mathrm{mRNA} \text { and } \\
\text { protein }\end{array}$ & $\begin{array}{l}\text { Downregulation causes } \\
\text { mammosphere formation. } \\
\text { Upregulation induces } \\
\text { sensitivity of cancer cells to } \\
\text { drug therapy. }\end{array}$ \\
\hline Takahasi et al. [34] & breast cancer cells & miR-27b & $\begin{array}{l}\downarrow \text { ENPP1 mRNA } \\
\text { and protein }\end{array}$ & $\begin{array}{l}\text { Downregulation causes } \\
\text { formation of SP fractions } \\
\text { that leads to drug resistance. } \\
\text { Upregulation inhibits the } \\
\text { expression of ABCG2 } \\
\text { transporter by } \\
\text { suppressing ENPP1. }\end{array}$ \\
\hline \multirow{2}{*}{ Bao et al. [35] } & MiaPaCa-2 & \multirow{2}{*}{ miR-26a } & $\begin{array}{l}\downarrow \text { EZH2, EpCAM } \\
\text { proteins and } \\
\text { mRNAs }\end{array}$ & \multirow{2}{*}{$\begin{array}{l}\text { Upregulation causes } \\
\text { decrease in the formation of } \\
\text { pancreatospheres. }\end{array}$} \\
\hline & $\begin{array}{l}\text { MiaPaCa-2 tumor } \\
\text { sphere }\end{array}$ & & $\begin{array}{c}\downarrow \text { EZH2, Oct4, } \\
\text { Notch-1, EpCAM } \\
\text { mRNAs }\end{array}$ & \\
\hline
\end{tabular}

$\downarrow$-downregulation; ATP-binding cassette super-family G member 2 (ABCG2) transporter; ectonucleotide pyrophosphatase/phosphodiesterase 1 (ENPP1); epithelial cell adhesion molecule (EpCAM); enhancer of zeste homolog 2 (EZH2); side-population cells (SP fraction).

\subsubsection{Metformin Molecular Targets}

All studies included for systematic review have analyzed the impact of metformin on selected miRNAs expression (Table 7). Tan et al. [33] demonstrated that in those cells treated with metformin, there was a significant increase of miR-708 expression and decrease of CD47 mRNA expression. Takahasi et al. [34] reported that metformin induced miR-27b-mediated suppression of ENPP1. Bao et al. [35] showed that metformin treatment increased the relative expressions of let-7a, let-7b, let-7c, miR-26a, miR-101, miR-200b and miR-200c in pancreatospheres. It was also found that metformin decreased the expressions of Oct4, Notch-1, EZH2 and Nanog mRNAs in pancreatospheres. Additionally, metformin inhibited the expression of CD44 and EpCAM in pancreatospheres [35]. Oliveras-Ferraros et al. [36] reported that metformin increased let-7A expression, downregulated TGF $\beta 1$-induced upregulation of miRNA-181a and suppressed TGF $\beta 1$-induced downregulation of miR-96. 
Table 7. Influence of metformin on expression of miRNAs, mRNAs and other molecules.

\begin{tabular}{|c|c|c|c|c|c|c|c|}
\hline Author & Type of Cells & Dose & Control & Time & $\begin{array}{l}\text { Expression of } \\
\text { miRNA }\end{array}$ & $\begin{array}{c}\text { Expression of } \\
\text { mRNA }\end{array}$ & $\begin{array}{l}\text { Expression of } \\
\text { Other Molecules }\end{array}$ \\
\hline \multirow[b]{2}{*}{ Tan et al. [33] } & $\begin{array}{c}\text { MCF-7.SC, } \\
\text { MAA-MB-231.SC }\end{array}$ & $10(\mathrm{mM}) \mathrm{Met}$ & PBS & $48 \mathrm{~h}$ & $\uparrow \mathrm{miR}-708$ & $\downarrow \mathrm{CD} 47$ & - \\
\hline & $\begin{array}{c}\text { MCF-7.SC } \\
\text { anti-miR-708, } \\
\text { MDA-MB-231.SC } \\
\text { anti-miR-708 }\end{array}$ & $\begin{array}{c}0.3,1.0,3.0(\mathrm{mM}) \\
\text { Met }\end{array}$ & $\begin{array}{c}\text { DMSO, } \\
\beta \text {-actin (loading } \\
\text { control) }\end{array}$ & $72 \mathrm{~h}$ & - & - & $\downarrow$ CD47 protein \\
\hline \multirow{2}{*}{ Takahasi et al. [34] } & $\begin{array}{c}\text { MCF-7 } \\
\text { co-transferred } \\
\text { with } \\
\text { pTK-GLuc027bs } \\
\text { and pSV40-CLuc }\end{array}$ & $\begin{array}{l}0.1,1.0,10.0 \\
100.0(\mathrm{mM})\end{array}$ & $0(\mathrm{mM}) \mathrm{Met}$ & $48 \mathrm{~h}$ & $\uparrow \mathrm{miR}-27 \mathrm{~b}$ & - & - \\
\hline & $\begin{array}{c}\text { MCF-7-luc } \\
\text { anti-miR-27b-DR, } \\
\text { ZR75-1-luc } \\
\text { anti-miR-27b }\end{array}$ & $\begin{array}{c}0.1,0.3,1.0 \\
3.0,10.0(\mathrm{mM})\end{array}$ & $\begin{array}{c}\text { DMSO, } \\
\beta \text {-actin } \\
\text { (loading control) }\end{array}$ & $72 \mathrm{~h}$ & - & - & $\downarrow$ ENPP1 protein \\
\hline \multirow[b]{2}{*}{ Bao et al. [35] } & $\begin{array}{l}\text { Pancreatospheres } \\
\text { of pancreatic } \\
\text { cancer cells }\end{array}$ & $20(\mathrm{mM}) \mathrm{Met}$ & $0(\mathrm{mM}) \mathrm{Met}$ & $1 \mathrm{w}$ & $\begin{array}{c}\uparrow \text { let-7a, let-7b, } \\
\text { let-7c, miR-26a, } \\
\text { miR-101, } \\
\text { miR-200b, } \\
\text { miR-200c }\end{array}$ & $\begin{array}{l}\downarrow \text { Oct4, Notch-1, } \\
\text { EZH2, Nanog * }\end{array}$ & - \\
\hline & $\begin{array}{c}\text { Secondary } \\
\text { pancreatospheres } \\
\text { of mouse } \\
\text { xenograft tumor } \\
\text { derived from } \\
\text { MiaPaCa-2 } \\
\text { sphere-forming } \\
\text { cells } \\
\end{array}$ & $20(\mathrm{mM}) \mathrm{Met}$ & $0(\mathrm{mM}) \mathrm{Met}$ & $1 \mathrm{w}$ & - & - & $\begin{array}{c}\downarrow \mathrm{CD} 44, \text { EpCAM } \\
\text { proteins }\end{array}$ \\
\hline $\begin{array}{c}\text { Oliveras-Ferraros et al. } \\
{[36]}\end{array}$ & MCF-7 & $\begin{array}{c}1,10(\mathrm{mM}) ; 1 \\
10(\mathrm{mM})+100 \\
(\mathrm{ng} / \mathrm{mL}) \mathrm{TGF} \beta 1\end{array}$ & $\begin{array}{c}0(\mathrm{mM}) \text { Met, } \\
0(\mathrm{ng} / \mathrm{mL}) \text { TGF } \beta 1\end{array}$ & $48 \mathrm{~h}$ & $\begin{array}{c}\uparrow \text { let-7a, miR-96, } \\
\downarrow \text { miR-181a, } \\
\text { miR-183 }\end{array}$ & - & - \\
\hline
\end{tabular}

$\uparrow$-upregulation; $\downarrow$-downregulation; dimethyl sulfoxide (DMSO); ectonucleotide pyrophosphatase/phosphodiesterase 1 (ENPP1); epithelial cell adhesion molecule (EpCAM); enhancer of zeste homolog 2 (EZH2); metformin (Met); phosphate-buffered saline (PBS); transforming growth factor $\beta 1$ (TGF $\beta 1$ ); ${ }^{*}$ Nanog mRNA relative expression was only decreased in pancreatospheres of MiaPaCa-2 and MiaPaCa-2-GTR cells. 


\subsubsection{Impact of Metformin on Major CSCs Functions}

Bao et al. [35] demonstrated that metformin decreased cell survival, clonogenicity, wound-healing capacity in all cell lines and invasion in parental MiaPaCa-2 and its tumor sphere cells. Moreover, it was also found that metformin either alone or in combination with difluorinated curcumin (CDF) inhibited the self-renewal ability of CSCs in primary and secondary pancreatospheres of all cell lines [35]. Authors showed that long-term metformin treatment decreased the formation of pancreatospheres induced by CSC-like cells [35]. Oliveras-Ferraros et al. [36] observed that cells treated with metformin exhibited significantly lower mammospheres-forming efficiencies (MFE), also when exposed to TGF $\beta 1$. Moreover, the aforementioned effect of metformin on miRNAs expression, taken together with the results described in this paragraph, suggest that the drug inactivates crucial functions to CSCs survival [33-36].

\section{Discussion}

\subsection{Summary of Evidence}

The aim of this systematic review was to evaluate the regulation of expression of various miRNAs in CSCs, underlying the anti-cancer properties of metformin. Cancer treatment is a great challenge for medicine, therefore understanding the molecular basis of multidrug resistance, metastasis or tumor relapse is key to developing new therapies with better therapeutic outcomes for oncology [24,28]. One potential way to treat cancer is to use agents that directly affect CSCs functions. CSCs have the capacity of self-renewal and differentiation potential; thus, they can contribute to cancer therapy resistance, metastasis and tumor relapse [18]. There are many transcription factors (Oct 4, Sox 2, Nanog, KLF4, MYC) or signaling pathways (Wnt/ $\beta$-catenin, Notch, Hh, NF-kB, JAK-STAT, TGF/Smad, PI3K/AKT/mTOR, PPAR) that are crucial in CSCs regulation. However, it is not fully understood how molecular mechanisms of CSCs are regulated [24].

In recent years, several miRNAs have been connected to anti-cancer mechanisms [37]. Moreover, down-regulation of some miRNAs was observed in tumors. Accordingly, miRNAs may affect major CSCs functions that lead to better outcomes of cancer patient treatment $[20,28,37]$. In this systematic review, researchers examined changes in expression of various types of miRNAs in CSCs listed below: miR-708, miR-27b, let-7a, let-7b, miR-101, miR-200b, miR-200c, miR-26a miR-181a and miR-96 [33-36]. miR-708 has been considered a cancer development suppressor in various types of cancers [38]. Previous studies showed that miR-708 overexpression led to decreased tumorigenesis through, for example, inhibition of cellular FLICE-like inhibitory protein (c-FLIP) [39], SMAD family member 3 (SMAD3) [40], zinc finger E-box-binding homeobox 1 (ZEB1) [41] or CD47 [42]. miR-27b is known for its dichotomous role in tumorigenesis. It has been reported that expression of miR-27b is increased in triple negative breast cancer $[43,44]$. On the other hand, miR-27b may act as suppressor gene in gastric cancer proliferation and metastasis by suppressing nuclear receptor subfamily 2 (NR2F2) [45]. Other miRNAs that have been found to be downregulated in cancers are the let-7 family. Mostly, let-7 are regulators of cell differentiation-downregulation of let-7 is a marker of less differentiated cancer $[46,47]$. Moreover, let-7 are linked to immunotherapy in various cancers through regulation of Toll-like receptors [48]. Various studies reported that miR-26a acts as a tumor suppressor by downregulating c-MYC pathway [49], cAMP regulated phosphoprotein 19 (ARPP19) [50], HOXC9 [51]. Other aforementioned miRNAs have also been linked to cancer suppression by regulating proliferation, apoptosis, metastasis and angiogenesis: miR-101 targets STMN1 [52], EZH2 [53]; miR-200 family members targets ZEB1 and SIP1 $[54,55]$. It must be noted that many miRNAs show a dichotomous role in tumorigenesis, besides the above mentioned miR-27b, for example, miR-181a [56] and miR-96 [57,58]. Published articles that have been analyzed in this systematic review focused on miRNAs expression in breast cancer [33,34,36] and pancreatic cancer [35]. Tan et al. [33] showed that expression of miR-708 was down-regulated in BCSCs. It has been reported that miR-708 regulates self-renewal capacity, phagocytosis and chemosensitivity in breast cancer. In addition, CD47 was identified as a direct target 
of miR-708 [33]. CD47 is a cell surface protein and its roles are crucial in immune system function and tumorigenesis. Prior studies have showed that CD47 is overexpressed in many hematopoietic and solid tumors and it correlates with worse clinical prognosis [59]. Takahasi et al. [34] identified gene encoding ENPP1 as a direct target of miR-27b that acts a tumor suppressor of breast cancer cells. Authors showed that miR-27b regulates the generation of an SP fraction that was linked to docetaxel resistance [34]. ENPP1 promotes the expression and cell surface localization of ABCG2 which is involved in the development of multidrug resistance, for example, in breast cancer, esophageal cancer, lung cancer [34,60-62]. Moreover, ENPP1 was reported as a promoter of generation of the SP fraction through upregulation of ABCG2 mRNA. ABCG2 regulates efflux activity of SP fraction that includes efflux of anticancer drugs [34]. In addition, Takashi et al. [34] reported that SP fraction was generated from miR-27b downregulated luminal-type breast cancer cells. Oliveras-Ferraros et al. [36] have identified let-7a downregulated expression in breast cancer cells that led to dedifferentiation and self-renewal capacity of cells. Moreover, TGF $\beta 1$ was found to upregulate miR-181a and downregulate miR-96 in breast cancer cells [36]. Previous studies confirmed that TGF $\beta 1$ induce sphere formation through upregulating miR-181a [63,64]. Bao et al. [35] showed that miR-26a plays a key role in the regulation of EZH2 and EpCAM mRNAs and proteins. Re-expression of miR-26a decreased the expression of EZH2 and EpCAM proteins and EZH2, Oct4 ${ }_{s}$ Notch-1 and EpCAM mRNAs [35]. EZH2 is the catalytic subunit of the polycomb repressive complex 2 (PRC2) and acts as lysine methyltransferase that is involved in the epigenetic regulation of gene transcription-methylation of histone $\mathrm{H} 3[65,66]$. It has been shown that EZH2 is overexpressed in many tumors, such as breast cancer, ALL, Burkitt lymphomas, and is associated with poor clinical prognosis [35,65]. Previous data revealed that miR-26a and miR-101 could downregulate EZH2 which decreases self-renewal capacity and induces apoptosis in cancer cells [53,67].

It has been presumed that metformin could block tumorigenesis by inactivation of CSCs. Various studies demonstrated that the mechanism of action of metformin is associated with AMPK/mTOR and insulin/IGF-1, MAPK and NF-KB signaling pathways [68,69]. Therefore, metformin antitumor effects are based on activation of AMPK or inhibition of mTOR [68]. It has been shown that metformin treated cancers exhibit antiproliferative effects, increased chemosensitivity, enhanced angiogenesis and prolonged tumor remission $[69,70]$. Thus, it appears that through the aforementioned pathways, metformin could inhibit self-renewal capacity, proliferation, migration and invasion of the CSCs $[28,69]$. However, the molecular mechanism of action of metformin remains unclear. One of the possible explanations is the modulation of various miRNAs expression that leads to major changes in functions of CSCs. As described above, studies included in this article demonstrated that CSCs could be eradicated by re-expression of miRNAs [33-36]. Moreover, all analyzed miRNAs were upregulated when metformin was added. Metformin modulates the following axes: miR-miR-708/CD47 in breast cancer [33], miR-27b/ENPP1 in breast cancer [34], 26a/EZH2 in pancreatic cancer [35], and blocks TGF $\beta 1$-induced upregulation of miR-181a and downregulation of miR-96 in breast cancer [36]. In addition, metformin also upregulates let-7 family, miR-200 family, miR-101 and Oct4, Notch-1, and EZH2 mRNAs in pancreatic cancer cells [35]. It has been showed that metformin inhibited sphere formation that suggests its major role in the inhibition of self-renewal capacity of CSCs $[35,36]$. All four studies analyzed reported positive effects of metformin in attenuating major CSCs functions through regulation of miRNAs expression (Figure 2) [33-36]. 


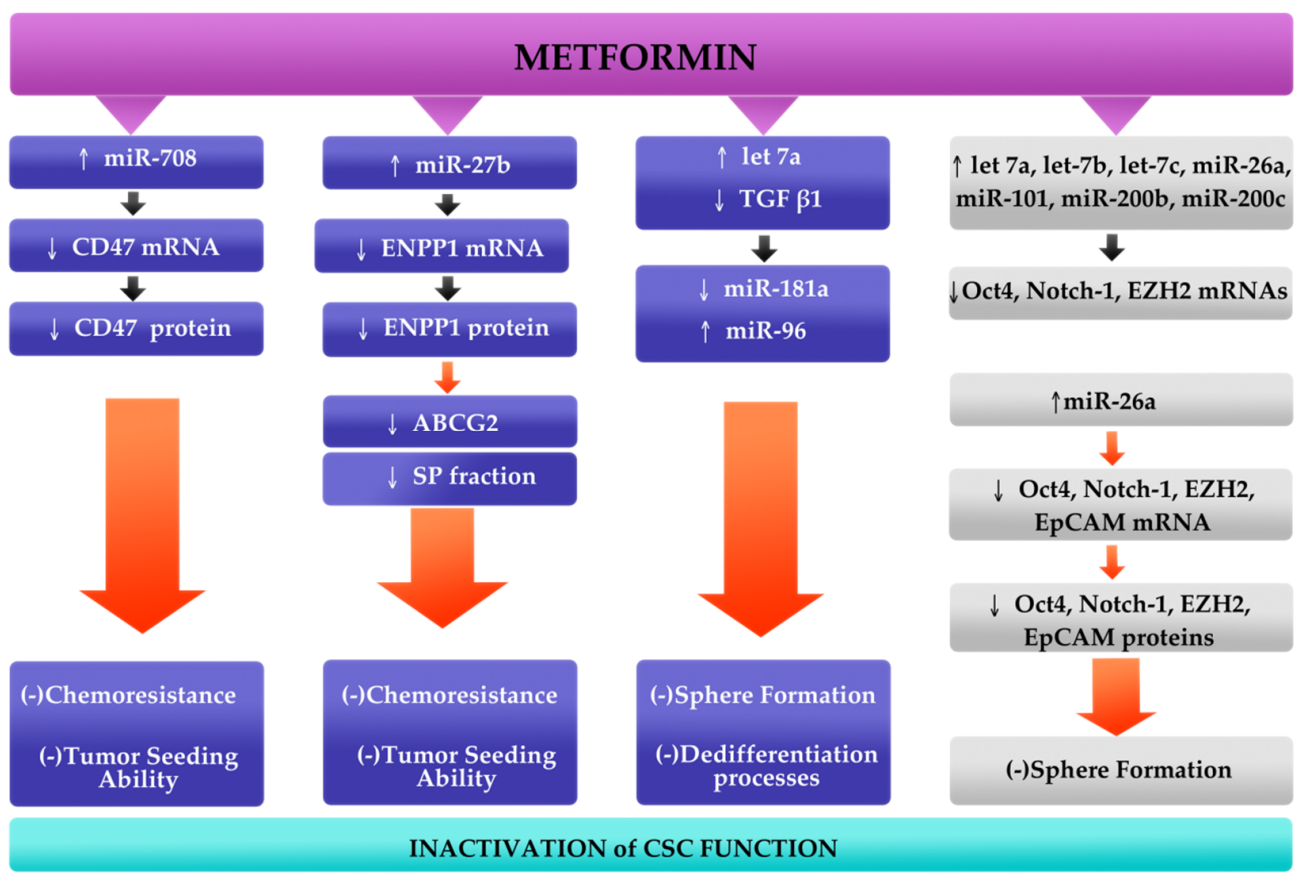

Figure 2. Conceptual mechanism of action of metformin. It has been reported that metformin upregulates miR-708, miR-27b and let-7a in breast cancer (blue blocks), and let-7 family, miR-200 family, miR-101 and miR-26a in pancreatic cancer (gray blocks). Metformin, through its ability to downregulate major cancer stem cells (CSCs) marker genes (CD47, ENPP1, EZH2, EpCAM, Oct4, Notch-1), acts as an anti-tumor agent that leads to suppression of chemoresistance, sphere formation and dedifferentiation processes and tumor seeding ability [33-36].

\subsection{Limitations}

This is the first systematic review that shows metformin effects on CSCs through regulation of expression of various miRNAs. There are limitations to this paper: included studies were performed on the cell lines but not on organisms, studies examined different miRNAs that make it impossible to analyze statistically, only two studies showed the effect of metformin on sphere formation and low number of studies were included. Therefore, performance of further investigations and clinical trials are required in order to bring a better understanding of the mechanism of action of metformin and the functions of CSCs.

\section{Conclusions}

In conclusion, this systematic review reports that metformin could inhibit tumorigenesis via targeted eradication of CSCs. The aforementioned studies show another possible mechanism of action of metformin which involves miRNAs. It is of great interest to fully and precisely understand the molecular role of metformin in the regulation of miRNAs. The above described preclinical studies implicate that metformin may improve therapeutic outcomes of breast and pancreatic cancer patients. However, functions of CSCs are still not fully understood and more studies are needed to examine CSCs molecular role in tumorigenesis. Apart from performing clinical trials on cancer patients, other areas of investigation may help in precisely understanding metformin-miRNA-CSC pathway. TCGA (The Cancer Genome Atlas) gave a better understanding of the genetic basis of the cancer through analyzing the genome. Therefore, computational tools may be useful in describing the molecular mechanism of action of metformin and its impact on miRNAs and CSCs. To sum up, further investigation is needed. 
Author Contributions: Conceptualization, N.M., B.M. and M.W.; methodology, N.M.; investigation, N.M. and B.M.; data curation, N.M. and B.M.; writing-Original draft preparation, N.M.; writing-Review and editing, N.M. and B.M.; visualization, B.M.; supervision, M.W. All authors have read and agreed to the published version of the manuscript.

Funding: This research received no external funding. The APC was funded by Collegium Medicum, Nicolaus Copernicus University, Torun, Poland

Conflicts of Interest: The authors declare no conflict of interest.

\section{References}

1. Reya, T.; Morrison, S.J.; Clarke, M.F.; Weissman, I.L. Stem cells, cancer, and cancer stem cells. Nature 2001, 414, 105-111. [CrossRef]

2. Chen, W.; Dong, J.; Haiech, J.; Kilhoffer, M.-C.; Zeniou, M. Cancer Stem Cell Quiescence and Plasticity as Major Challenges in Cancer Therapy. Stem Cells Int. 2016, 2016, 1740936. [CrossRef]

3. Lapidot, T.; Sirard, C.; Vormoor, J.; Murdoch, B.; Hoang, T.; Caceres-Cortes, J.; Minden, M.; Paterson, B.; Caligiuri, M.A.; Dick, J.E. A cell initiating human acute myeloid leukaemia after transplantation into SCID mice. Nature 1994, 367, 645-648. [CrossRef]

4. Bonnet, D.; Dick, J.E. Human acute myeloid leukemia is organized as a hierarchy that originates from a primitive hematopoietic cell. Nat. Med. 1997, 3, 730-737. [CrossRef]

5. Al-Hajj, M.; Wicha, M.S.; Benito-Hernandez, A.; Morrison, S.J.; Clarke, M.F. Prospective identification of tumorigenic breast cancer cells. Proc. Natl. Acad. Sci. USA 2003, 100, 3983-3988. [CrossRef]

6. Szotek, P.P.; Pieretti-Vanmarcke, R.; Masiakos, P.T.; Dinulescu, D.M.; Connolly, D.; Foster, R.; Dombkowski, D.; Preffer, F.; MacLaughlin, D.T.; Donahoe, P.K. Ovarian cancer side population defines cells with stem cell-like characteristics and Mullerian Inhibiting Substance responsiveness. Proc. Natl. Acad. Sci. USA 2006, 103, 11154-11159. [CrossRef]

7. Zhang, S.; Balch, C.; Chan, M.W.; Lai, H.-C.; Matei, D.; Schilder, J.M.; Yan, P.S.; Huang, T.H.-M.; Nephew, K.P. Identification and Characterization of Ovarian Cancer-Initiating Cells from Primary Human Tumors. Cancer Res. 2008, 68, 4311-4320. [CrossRef]

8. Hermann, P.C.; Huber, S.L.; Herrler, T.; Aicher, A.; Ellwart, J.W.; Guba, M.; Bruns, C.J.; Heeschen, C. Distinct populations of cancer stem cells determine tumor growth and metastatic activity in human pancreatic cancer. Cell Stem Cell 2007, 1, 313-323. [CrossRef]

9. Li, C.; Lee, C.J.; Simeone, D.M. Identification of human pancreatic cancer stem cells. Methods Mol. Biol. 2009, $568,161-173$.

10. Ginestier, C.; Hur, M.H.; Charafe-Jauffret, E.; Monville, F.; Dutcher, J.; Brown, M.; Jacquemier, J.; Viens, P.; Kleer, C.G.; Liu, S.; et al. ALDH1 Is a Marker of Normal and Malignant Human Mammary Stem Cells and a Predictor of Poor Clinical Outcome. Cell Stem Cell 2007, 1, 555-567. [CrossRef]

11. Patrawala, L.; Calhoun, T.; Schneider-Broussard, R.; Li, H.; Bhatia, B.; Tang, S.; Reilly, J.G.; Chandra, D.; Zhou, J.; Claypool, K.; et al. Highly purified CD44+ prostate cancer cells from xenograft human tumors are enriched in tumorigenic and metastatic progenitor cells. Oncogene 2006, 25, 1696-1708. [CrossRef] [PubMed]

12. Patrawala, L.; Calhoun-Davis, T.; Schneider-Broussard, R.; Tang, D.G. Hierarchical organization of prostate cancer cells in xenograft tumors: The CD44+alpha2beta1+ cell population is enriched in tumor-initiating cells. Cancer Res. 2007, 67, 6796-6805. [CrossRef] [PubMed]

13. Li, T.; Su, Y.; Mei, Y.; Leng, Q.; Leng, B.; Liu, Z.; Stass, S.A.; Jiang, F. ALDH1A1 is a marker for malignant prostate stem cells and predictor of prostate cancer patients' outcome. Lab. Investig. 2010, 90, $234-244$. [CrossRef]

14. Gao, M.-Q.; Choi, Y.-P.; Kang, S.; Youn, J.H.; Cho, N.-H. CD24+ cells from hierarchically organized ovarian cancer are enriched in cancer stem cells. Oncogene 2010, 29, 2672-2680. [CrossRef]

15. Silva, I.A.; Bai, S.; McLean, K.; Yang, K.; Griffith, K.; Thomas, D.; Ginestier, C.; Johnston, C.; Kueck, A.; Reynolds, R.K.; et al. Aldehyde dehydrogenase in combination with CD133 defines angiogenic ovarian cancer stem cells that portend poor patient survival. Cancer Res. 2011, 71, 3991-4001. [CrossRef]

16. Baba, T.; Convery, P.A.; Matsumura, N.; Whitaker, R.S.; Kondoh, E.; Perry, T.; Huang, Z.; Bentley, R.C.; Mori, S.; Fujii, S.; et al. Epigenetic regulation of CD133 and tumorigenicity of CD133+ ovarian cancer cells. Oncogene 2009, 28, 209-218. [CrossRef] 
17. Tang, D.G. Understanding cancer stem cell heterogeneity and plasticity. Cell Res. 2012, 22, 457-472. [CrossRef]

18. Ajani, J.A.; Song, S.; Hochster, H.S.; Steinberg, I.B. Cancer Stem Cells: The Promise and the Potential. Semin. Oncol. 2015, 42, S3-S17. [CrossRef]

19. Borah, A.; Raveendran, S.; Rochani, A.; Maekawa, T.; Kumar, D.S. Targeting self-renewal pathways in cancer stem cells: Clinical implications for cancer therapy. Oncogenesis 2015, 4, e177. [CrossRef]

20. Takahashi, R.; Miyazaki, H.; Ochiya, T. The role of microRNAs in the regulation of cancer stem cells. Front. Genet. 2014, 4, 295. [CrossRef]

21. Bartel, D.P. MicroRNAs: Genomics, Biogenesis, Mechanism, and Function. Cell 2004, 116, 281-297. [CrossRef]

22. O'Hara, S.P.; Mott, J.L.; Splinter, P.L.; Gores, G.J.; Larusso, N.F. MicroRNAs: Key Modulators of Posttranscriptional Gene Expression. Gastroenterology 2009, 136, 17-25. [CrossRef]

23. Prokopi, M.; Kousparou, C.A.; Epenetos, A.A. The Secret Role of microRNAs in Cancer Stem Cell Development and Potential Therapy: A Notch-Pathway Approach. Front. Oncol. 2015, 4, 389. [CrossRef]

24. Yang, L.; Shi, P.; Zhao, G.; Xu, J.; Peng, W.; Zhang, J.; Zhang, G.; Wang, X.; Dong, Z.; Chen, F.; et al. Targeting cancer stem cell pathways for cancer therapy. Signal. Transduct. Target. Ther. 2020, 5, 1-35. [CrossRef]

25. Phi, L.T.H.; Sari, I.N.; Yang, Y.-G.; Lee, S.-H.; Jun, N.; Kim, K.S.; Lee, Y.K.; Kwon, H.Y. Cancer Stem Cells (CSCs) in Drug Resistance and their Therapeutic Implications in Cancer Treatment. Stem Cells Int. 2018, 2018, 5416923. [CrossRef]

26. Pedroza-Torres, A.; Romero-Córdoba, S.L.; Justo-Garrido, M.; Salido-Guadarrama, I.; Rodríguez-Bautista, R.; Montaño, S.; Muñiz-Mendoza, R.; Arriaga-Canon, C.; Fragoso-Ontiveros, V.; Álvarez-Gómez, R.M.; et al. MicroRNAs in Tumor Cell Metabolism: Roles and Therapeutic Opportunities. Front. Oncol. 2019, 9, 1404. [CrossRef]

27. Pulito, C.; Donzelli, S.; Muti, P.; Puzzo, L.; Strano, S.; Blandino, G. microRNAs and cancer metabolism reprogramming: The paradigm of metformin. Ann. Transl. Med. 2014, 2, 58.

28. Bao, B.; Azmi, A.S.; Ali, S.; Zaiem, F.; Sarkar, F.H. Metformin may function as anti-cancer agent via targeting cancer stem cells: The potential biological significance of tumorassociated miRNAs in breast and pancreatic cancers. Ann. Transl. Med. 2014, 2, 59.

29. El-Mir, M.Y.; Nogueira, V.; Fontaine, E.; Avéret, N.; Rigoulet, M.; Leverve, X. Dimethylbiguanide inhibits cell respiration via an indirect effect targeted on the respiratory chain complex I. J. Biol. Chem. 2000, 275, 223-228. [CrossRef]

30. Sanders, M.J.; Grondin, P.O.; Hegarty, B.D.; Snowden, M.A.; Carling, D. Investigating the mechanism for AMP activation of the AMP-activated protein kinase cascade. Biochem. J. 2007, 403, 139-148. [CrossRef]

31. Zhou, G.; Myers, R.; Li, Y.; Chen, Y.; Shen, X.; Fenyk-Melody, J.; Wu, M.; Ventre, J.; Doebber, T.; Fujii, N.; et al. Role of AMP-activated protein kinase in mechanism of metformin action. J. Clin. Investig. 2001, 108, 1167-1174. [CrossRef]

32. Golbach, L.A.; Portelli, L.A.; Savelkoul, H.F.J.; Terwel, S.R.; Kuster, N.; de Vries, R.B.M.; Verburg-van Kemenade, B.M.L. Calcium homeostasis and low-frequency magnetic and electric field exposure: A systematic review and meta-analysis of in vitro studies. Environ. Int. 2016, 92-93, 695-706. [CrossRef]

33. Tan, W.; Tang, H.; Jiang, X.; Ye, F.; Huang, L.; Shi, D.; Li, L.; Huang, X.; Li, L.; Xie, X.; et al. Metformin mediates induction of miR-708 to inhibit self-renewal and chemoresistance of breast cancer stem cells through targeting CD47. J. Cell. Mol. Med. 2019, 23, 5994-6004. [CrossRef]

34. Takahashi, R.; Miyazaki, H.; Takeshita, F.; Yamamoto, Y.; Minoura, K.; Ono, M.; Kodaira, M.; Tamura, K.; Mori, M.; Ochiya, T. Loss of microRNA-27b contributes to breast cancer stem cell generation by activating ENPP1. Nat. Commun. 2015, 6, 7318. [CrossRef]

35. Bao, B.; Wang, Z.; Ali, S.; Ahmad, A.; Azmi, A.S.; Sarkar, S.H.; Banerjee, S.; Kong, D.; Li, Y.; Thakur, S.; et al. Metformin Inhibits Cell Proliferation, Migration and Invasion by Attenuating CSC Function Mediated by Deregulating miRNAs in Pancreatic Cancer Cells. Cancer Prev. Res. 2012, 5, 355-364. [CrossRef]

36. Oliveras-Ferraros, C.; Cufí, S.; Vazquez-Martin, A.; Torres-Garcia, V.Z.; Del Barco, S.; Martin-Castillo, B.; Menendez, J.A. Micro(mi)RNA expression profile of breast cancer epithelial cells treated with the anti-diabetic drug metformin: Induction of the tumor suppressor miRNA let-7a and suppression of the TGF $\beta$-induced oncomiR miRNA-181a. Cell Cycle 2011, 10, 1144-1151. [CrossRef]

37. Asadzadeh, Z.; Mansoori, B.; Mohammadi, A.; Aghajani, M.; Haji-Asgarzadeh, K.; Safarzadeh, E.; Mokhtarzadeh, A.; Duijf, P.H.G.; Baradaran, B. microRNAs in cancer stem cells: Biology, pathways, and therapeutic opportunities. J. Cell. Physiol. 2019, 234, 10002-10017. [CrossRef] 
38. Monteleone, N.J.; Lutz, C.S. miR-708-5p: A microRNA with emerging roles in cancer. Oncotarget 2017, 8, 71292-71316. [CrossRef]

39. Kim, E.-A.; Kim, S.-W.; Nam, J.; Sung, E.-G.; Song, I.-H.; Kim, J.-Y.; Kwon, T.K.; Lee, T.-J. Inhibition of c-FLIPL expression by miRNA-708 increases the sensitivity of renal cancer cells to anti-cancer drugs. Oncotarget 2016, 7, 31832-31846. [CrossRef]

40. Li, Q.; Li, S.; Wu, Y.; Gao, F. miRNA-708 functions as a tumour suppressor in hepatocellular carcinoma by targeting SMAD3. Oncol. Lett. 2017, 14, 2552-2558. [CrossRef]

41. Sun, S.; Hang, T.; Zhang, B.; Zhu, L.; Wu, Y.; Lv, X.; Huang, Q.; Yao, H. miRNA-708 functions as a tumor suppressor in colorectal cancer by targeting ZEB1 through Akt/mTOR signaling pathway. Am. J. Transl. Res. 2019, 11, 5338-5356. [PubMed]

42. Huang, W.; Wang, W.-T.; Fang, K.; Chen, Z.-H.; Sun, Y.-M.; Han, C.; Sun, L.-Y.; Luo, X.-Q.; Chen, Y.-Q. MIR-708 promotes phagocytosis to eradicate T-ALL cells by targeting CD47. Mol. Cancer 2018, 17, 12. [CrossRef] [PubMed]

43. Jin, L.; Wessely, O.; Marcusson, E.G.; Ivan, C.; Calin, G.A.; Alahari, S.K. Pro-oncogenic factors miR-23b and miR-27b are regulated by Her2/Neu, EGF, and TNF $\alpha$ in breast cancer. Cancer Res. 2013, 73, $2884-2896$. [CrossRef] [PubMed]

44. Hannafon, B.N.; Cai, A.; Calloway, C.L.; Xu, Y.-F.; Zhang, R.; Fung, K.-M.; Ding, W.-Q. miR-23b and miR-27b are oncogenic microRNAs in breast cancer: Evidence from a CRISPR/Cas9 deletion study. BMC Cancer 2019, 19, 642. [CrossRef]

45. Feng, Q.; Wu, X.; Li, F.; Ning, B.; Lu, X.; Zhang, Y.; Pan, Y.; Guan, W. miR-27b inhibits gastric cancer metastasis by targeting NR2F2. Protein Cell 2017, 8, 114-122. [CrossRef] [PubMed]

46. Chirshev, E.; Oberg, K.C.; Ioffe, Y.J.; Unternaehrer, J.J. Let-7 as biomarker, prognostic indicator, and therapy for precision medicine in cancer. Clin. Transl. Med. 2019, 8, 24. [CrossRef]

47. Shell, S.; Park, S.-M.; Radjabi, A.R.; Schickel, R.; Kistner, E.O.; Jewell, D.A.; Feig, C.; Lengyel, E.; Peter, M.E. Let-7 expression defines two differentiation stages of cancer. Proc. Natl. Acad. Sci. USA 2007, 104, 11400-11405. [CrossRef]

48. Gilles, M.-E.; Slack, F.J. Let-7 microRNA as a potential therapeutic target with implications for immunotherapy. Expert Opin. Ther. Targets 2018, 22, 929-939. [CrossRef]

49. Li, J.; Liang, Y.; Lv, H.; Meng, H.; Xiong, G.; Guan, X.; Chen, X.; Bai, Y.; Wang, K. miR-26a and miR-26b inhibit esophageal squamous cancer cell proliferation through suppression of c-MYC pathway. Gene 2017, 625, 1-9. [CrossRef]

50. Gong, Y.; Wu, W.; Zou, X.; Liu, F.; Wei, T.; Zhu, J. MiR-26a inhibits thyroid cancer cell proliferation by targeting ARPP19. Am. J. Cancer Res. 2018, 8, 1030-1039.

51. Peng, X.; Kang, Q.; Wan, R.; Wang, Z. miR-26a/HOXC9 Dysregulation Promotes Metastasis and Stem Cell-Like Phenotype of Gastric Cancer. Cell. Physiol. Biochem. Int. J. Exp. Cell. Physiol. Biochem. Pharmacol. 2018, 49, 1659-1676. [CrossRef] [PubMed]

52. Zhu, L.; Chen, Y.; Nie, K.; Xiao, Y.; Yu, H. MiR-101 inhibits cell proliferation and invasion of pancreatic cancer through targeting STMN1. Cancer Biomark. Sect. Dis. Markers 2018, 23, 301-309. [CrossRef] [PubMed]

53. Wang, C.; Liu, B. miR-101-3p induces autophagy in endometrial carcinoma cells by targeting EZH2. Arch. Gynecol. Obstet. 2018, 297, 1539-1548. [CrossRef] [PubMed]

54. Gregory, P.A.; Bert, A.G.; Paterson, E.L.; Barry, S.C.; Tsykin, A.; Farshid, G.; Vadas, M.A.; Khew-Goodall, Y.; Goodall, G.J. The miR-200 family and miR-205 regulate epithelial to mesenchymal transition by targeting ZEB1 and SIP1. Nat. Cell Biol. 2008, 10, 593-601. [CrossRef]

55. Diaz-Riascos, Z.V.; Ginesta, M.M.; Fabregat, J.; Serrano, T.; Busquets, J.; Buscail, L.; Cordelier, P.; Capellá, G. Expression and Role of MicroRNAs from the miR-200 Family in the Tumor Formation and Metastatic Propensity of Pancreatic Cancer. Mol. Ther. Nucleic Acids 2019, 17, 491-503. [CrossRef]

56. Yang, C.; Tabatabaei, S.N.; Ruan, X.; Hardy, P. The Dual Regulatory Role of MiR-181a in Breast Cancer. Cell. Physiol. Biochem. Int. J. Exp. Cell. Physiol. Biochem. Pharmacol. 2017, 44, 843-856. [CrossRef]

57. Vahabi, M.; Pulito, C.; Sacconi, A.; Donzelli, S.; D'Andrea, M.; Manciocco, V.; Pellini, R.; Paci, P.; Sanguineti, G.; Strigari, L.; et al. miR-96-5p targets PTEN expression affecting radio-chemosensitivity of HNSCC cells. J. Exp. Clin. Cancer Res. 2019, 38, 141. [CrossRef]

58. Xu, T.; Du, X.-W.; Hu, J.-B.; Zhu, Y.-F.; Wu, H.-L.; Dai, G.-P.; Shu, Y.-M.; Ouyang, J. Anticancer effect of miR-96 inhibitor in bladder cancer cell lines. Oncol. Lett. 2018, 15, 3814-3819. [CrossRef] 
59. Zeng, D.; Sun, Q.; Chen, A.; Fan, J.; Yang, X.; Xu, L.; Du, P.; Qiu, W.; Zhang, W.; Wang, S.; et al. A fully human anti-CD47 blocking antibody with therapeutic potential for cancer. Oncotarget 2016, 7, 83040-83050. [CrossRef]

60. Mao, Q.; Unadkat, J.D. Role of the Breast Cancer Resistance Protein (BCRP/ABCG2) in Drug Transport-An Update. AAPS J. 2014, 17, 65-82. [CrossRef] [PubMed]

61. Wang, L.; Liu, L.; Chen, Y.; Du, Y.; Wang, J.; Liu, J. Correlation between adenosine triphosphate (ATP)-binding cassette transporter G2 (ABCG2) and drug resistance of esophageal cancer and reversal of drug resistance by artesunate. Pathol. Res. Pract. 2018, 214, 1467-1473. [CrossRef] [PubMed]

62. Tang, Y.; Hou, J.; Li, G.; Song, Z.; Li, X.; Yang, C.; Liu, W.; Hu, Y.; Xu, Y. ABCG2 regulates the pattern of self-renewing divisions in cisplatin-resistant non-small cell lung cancer cell lines. Oncol. Rep. 2014, 32, 2168-2174. [CrossRef] [PubMed]

63. Taylor, M.A.; Sossey-Alaoui, K.; Thompson, C.L.; Danielpour, D.; Schiemann, W.P. TGF- $\beta$ upregulates miR-181a expression to promote breast cancer metastasis. J. Clin. Investig. 2013, 123, 150-163. [CrossRef] [PubMed]

64. Suzuki, H.I. MicroRNA Control of TGF- $\beta$ Signaling. Int. J. Mol. Sci. 2018, 19, 1901. [CrossRef]

65. Herviou, L.; Cavalli, G.; Cartron, G.; Klein, B.; Moreaux, J. EZH2 in normal hematopoiesis and hematological malignancies. Oncotarget 2015, 7, 2284-2296. [CrossRef]

66. Li, B.; Chng, W.-J. EZH2 abnormalities in lymphoid malignancies: Underlying mechanisms and therapeutic implications. J. Hematol. Oncol.J Hematol Oncol 2019, 12, 118. [CrossRef]

67. Chen, J.; Xu, Y.; Tao, L.; Pan, Y.; Zhang, K.; Wang, R.; Chen, L.-B.; Chu, X. MiRNA-26a Contributes to the Acquisition of Malignant Behaviors of Doctaxel-Resistant Lung Adenocarcinoma Cells through Targeting EZH2. Cell. Physiol. Biochem. Int. J. Exp. Cell. Physiol. Biochem. Pharmacol. 2017, 41, 583-597. [CrossRef]

68. Lei, Y.; Yi, Y.; Liu, Y.; Liu, X.; Keller, E.T.; Qian, C.-N.; Zhang, J.; Lu, Y. Metformin targets multiple signaling pathways in cancer. Chin. J. Cancer 2017, 36, 17. [CrossRef]

69. Mallik, R.; Chowdhury, T.A. Metformin in cancer. Diabetes Res. Clin. Pract. 2018, 143, 409-419. [CrossRef]

70. Morales, D.R.; Morris, A.D. Metformin in cancer treatment and prevention. Annu. Rev. Med. 2015, 66, 17-29. [CrossRef] 